\title{
The Effectiveness of Kegel Exercise for the Acceleration of Perineum Wound Healing on Postpartum Women
}

\author{
$1^{\text {st }} \mathrm{R}$ Gustirini \\ Midwifery Study Program \\ STIKes Muhammadiyah Palembang \\ Palembang, Indonesia \\ riagustirini@gmail.com \\ $4^{\text {th }}$ Mardalena \\ Midwifery Study Program \\ STIKes Muhammadiyah Palembang \\ Palembang, Indonesia
}

\author{
$2^{\text {nd }} \mathrm{RN}$ Pratama \\ Midwifery Study Program \\ STIKes Muhammadiyah Palembang \\ Palembang, Indonesia
}

\author{
$3^{\text {rd }}$ RAA Maya \\ Midwifery Study Program \\ STIKes Muhammadiyah Palembang \\ Palembang, Indonesia
}

\begin{abstract}
Postpartum is an important phase because the complication including genetalia infection frequently happen in this phase. perineum wound healing delay is influenced by several factors, such as less nutrients, less of personal hygiene or personal perineum hygiene, less break, less mobilization and exercises as post-partum exercises that could cause infection. The Post-partum Mobilization was applied gradually based on mother's power. One effort to be made to accelerate perineum wound healing was to implement post-partum exercise. One movement in postpartum exercise including kegel exercise was useful to help perineum wound healing. In this study, we aimed to Analyze the effectiveness of kegel exercise for the acceleration of perineum wound healing. Methods: The quantitative method with quasi experiment, the sampling technique used in this research was purposive sampling. Results: There is a meaningful correlation ( $p$-value $<0,05$ ) on accelerating of perineum wound healing between the postpartum women who implemented the kegel exercise compared to women who did not do kegel exercise. Conclusion: kegel exercise was recommended to be done for a beginning week of postpartum to help the accelerate perineum wound healing.
\end{abstract}

Keywords -kegel, healing, postpartum women

\section{INTRODUCTION}

Around 600,000 women are estimated to die from complications related to pregnancy and childbirth and the puerperium each year. Most of these deaths occur in developing countries. Most of the Maternal Mortality Rate (MMR) occurs during labor mainly due to bleeding. Maternal women generally experience tears in the vagina and perineum which cause bleeding in varying amounts and a lot [1]. Indonesia's maternal mortality rate is still the highest among ASEAN countries. The direct causes of maternal deaths in Indonesia and other countries are almost the same, which is around (11\%) caused by infection [2].

Perineal laceration is a tear that occurs in the perineum during labor. Perineal laceration can be classified based on the degree of laceration, namely degree I, degree II, degree III, and degree IV. A study conducted in the UK shows that $85 \%$ of women who give birth normally will experience perineal trauma. More than two-thirds of these women will require sewing. Perineal trauma will affect women's physical, psychological, and social well-being in the immediate and long-term postnatal period [3]. The puerperium infection can be caused by a birth canal wound that is not undergoing a healing process well [4].

Usually the healing of wounds in these perineal tears will heal varies, some are healed normally and some are delayed in healing. Effective mobilization is carried out for postpartum mothers in accelerating the process of healing perineal wounds with Kegel exercises, including to improve blood circulation, renew body posture, improve pelvic muscles / pelvic floor of a woman [5].

Kegel exercises are exercises to strengthen the pelvic floor muscles found by Dr. Arnold Kegel. Pelvic muscle or PC (Pubococcygeal Muscle) is muscle attached to the pelvic bones like a swing and plays a role in moving the pelvic organs. Kegel exercise or Kegel exercises can reduce laceration that occurs due to vaginal delivery, increase vaginal muscle tone, decrease perineal edema and increase circulation in the perineal area so that it can improve healing of perineal wounds [6].

Unfortunately, almost $50 \%$ of women find it difficult to do Kegel exercises properly, Therefore, it is very important to teach mothers as early as possible about Kegel exercises techniques correctly [1]. Authors hope that this research can contribute to the science of midwifery about efforts to accelerate the healing of perineal wounds in postpartum mothers through Kegel exercises. The purpose of this study was to analyze the effectiveness of Kegel exercises on the acceleration of perineal wound healing.

\section{METHOD}

This research uses a quantitative approach, the method used in this study is a quasi-experimental post-test only control group design. The study population was postpartum mothers at midwives independent practice "Husniyati Midwife". The sampling technique was 
purposive sampling. The sample of this study was 30 respondents divided into 15 treatments 15 controls that met the inclusion criteria. The inclusion criteria are as follows: Mother Post-Partum first day with grade 2 perineum tears; Mothers give birth normally in midwives independent practice; Mother does not abstain from eating during the observation process; The condition of the wound at the time of starting observation there are no signs of infection. Exclusion Criteria are: Mothers who are not willing to be the subject of research; Mothers who do not have complete delivery records.

Kegel exercises technique are: The simplest and easiest Kegel exercises are done as if holding urine; Tighten or contract the muscles such as holding urine, hold for 5 seconds, then relax (relax) for 5 seconds; Repeat the exercise at least five times a day (25 contractions).

Kegel exercises were carried out for 7 days in the treatment group, whereas in the control group, TABLE 1. FREQUENCY DISTRIBUTION BASED ON RESPONDENT

\begin{tabular}{|c|c|c|c|c|c|c|c|}
\hline \multirow{3}{*}{ Group } & \multicolumn{4}{|c|}{ Age of Respondent } & \multirow{2}{*}{\multicolumn{2}{|c|}{ Total }} & \multirow[t]{3}{*}{$\mathrm{p}$-value } \\
\hline & \multicolumn{2}{|c|}{ High Risk } & \multicolumn{2}{|c|}{ Low Risk } & & & \\
\hline & $\mathbf{F}$ & $\%$ & $\mathbf{F}$ & $\%$ & $\mathbf{F}$ & $\%$ & \\
\hline Treatments & 1 & 6.7 & 14 & 93.3 & 15 & 100 & 1.000 \\
\hline Controls & 1 & 6.7 & 14 & 93.3 & 15 & 100 & \\
\hline
\end{tabular}

Table 1 shows that most of the respondents from both the treatment and control group had an age with a low risk category, namely those aged 20-35 years by $93.3 \%$ and a small proportion of respondents both from the treatment and control group had an age with a high risk category that was with an age $>20$ years. and $<35$ years by $6.7 \%$. Table 1 shows that there were no significant differences in the

TABLE 2. FREQUENCY DISTRIBUTION BASED ON RESPONDENT PARITY

\begin{tabular}{|c|c|c|c|c|c|c|c|}
\hline \multirow{3}{*}{ Group } & \multicolumn{4}{|c|}{ parity of Respondent } & \multirow{3}{*}{$\begin{array}{l}\text { Total } \\
\mathrm{F}\end{array}$} & & \multirow[t]{3}{*}{$\mathrm{p}$ Value } \\
\hline & \multicolumn{2}{|c|}{ Primipara } & \multicolumn{2}{|c|}{ Multipara } & & & \\
\hline & $\mathrm{F}$ & $\%$ & $\mathrm{~F}$ & $\%$ & & $\%$ & \\
\hline Treatments & 4 & 26.7 & 11 & 73.3 & 15 & 100 & 1.000 \\
\hline Controls & 3 & 20 & 12 & 80 & 15 & 100 & \\
\hline
\end{tabular}

Table 2 shows the frequency distribution of respondents based on parity, there were 4 respondents $(26.7 \%)$ and 11 respondents $(73.3 \%)$ in primipara in the treatment group, and 3 respondents $(20 \%)$ and 12 respondents in multipara and 12 respondents $(80 \%)$ in B. Bivariate Analysis

TABLE 3. THE EFFECTIVENESS OF KEGEL EXERCISE FOR THE ACCELERATION OF PERINEUM WOUND HEALING

\begin{tabular}{|c|c|c|c|c|c|c|c|}
\hline \multirow{3}{*}{ Group } & \multicolumn{4}{|c|}{ Perineum wound healing } & \multirow{3}{*}{$\begin{array}{l}\text { Total } \\
\text { F }\end{array}$} & \multirow[b]{3}{*}{$\%$} & \multirow{3}{*}{$p$-value } \\
\hline & \multicolumn{2}{|c|}{ the acceleracy } & \multicolumn{2}{|c|}{ Delay } & & & \\
\hline & $\mathrm{F}$ & $\%$ & $\mathrm{~F}$ & $\%$ & & & \\
\hline Treatments & 12 & 80 & 3 & 20 & 15 & 100 & \\
\hline Controls & 5 & 33.3 & 10 & 66,7 & 15 & 100 & 0,010 \\
\hline Total & 17 & 60 & 13 & 40 & 30 & 100 & \\
\hline
\end{tabular}

The results in table 3 show that the healing of perineal wounds in mothers who performed Kegel exercises (treatment group) was faster by 12 respondents (80\%) multipara control group. Table 2 shows that there were no significant differences in the characteristics of postpartum maternal parity between the treatment and control groups $(\mathrm{p}>0.05)$. respondents were only given counseling to keep the was carried out on the eighth day in both the treatment and control groups. The wound was declared healed if the dry wound had no redness, no swelling, unified tissue, and no pain when sitting and walking [7].

\section{RESULT} postpartum mothers" as follows:

\section{1) Age of Respondents}

The frequency distribution of respondents based on age distribution can be seen in the following table:
The frequency distribution of respondents' parity in this study can be seen in the following table:

(treatment group) was faster by 12 respondents (80\%)

compared to mothers without Kegel exercises (control),
which was 5 respondents $(33.3 \%)$. Chi-Square test results obtained $\mathrm{p}$ value of 0.010 so that there is a significant 
relationship between Kegel exercises with accelerated healing of perineal wounds in postpartum mothers ( $p$ $<0.05)$.

\section{DISCUSSION}

Kegel exercises are a series of exercises designed to strengthen the pelvic floor muscles. Kegel exercises are exercises that aim to strengthen the pelvic floor muscles, especially the Puboccoccygeus (PC) or pelvic floor muscle, so that a woman can strengthen the muscles of the urinary tract and vaginal muscles [8]. This exercises movement was introduced in 1948 by Dr. Arnold Henry Kegel, an obstetrician from the United States. Since then, pelvic floor muscle training is widely practiced, one of which is as a non-pharmacological and non-surgical therapy in cases of urinary incontinence. Kegel exercises are very simple and easy to do, but they can also be done in privacy. This is beneficial, because it can do it anywhere and anytime. In a sitting position in an office chair or even when lying down. The point is Kegel exercises can be done and used as a positive habit at any time [1]

Based on table 3 there were 12 respondents (80\%) who experienced perineal wound healing in the fast category and only 3 respondents $(20 \%)$ who experienced perineal wound healing in the old category in the group that performed Kegel exercises. The process of wound healing is relatively faster in postpartum mothers who exercise Kegel exercises compared to postpartum mothers who do not do Kegel exercises. This is in line with the theory which states that Kegel exercises can strengthen pelvic floor muscles, increase perinel elasticity and improve perineal blood circulation so as to accelerate the process of healing perineal wounds [2].

Perineal healing is the time measured from the perineal suturing until the wound closes, is dry and there are no signs of infection (red, swollen, hot and painful). Usually the healing of wounds on these perineal tears will heal varies, some are healed normally and some are delayed. The wound was declared healed if the dry wound had no redness, no swelling, unified tissue, and no pain when sitting and walking [7]. In this study, postpartum mothers given Kegel exercises relatively showed signs of healing of perineal wounds faster than postpartum mothers who show relatively longer signs of perineal wound healing.

\section{CONCLUSION}

Kegel exercises are effective during the early weeks of the puerperium to help accelerate the healing of perineal wounds in postpartum mothers with grade 2 perineal wounds.

\section{ACKNOWLEDGMENTS}

Thanks to the chairman of the STIKes Muhammadiyah Palembang, the Head of the P2M institution, that has provided the funding for this research through the Hibah STIKes Muhammadiyah Palembang.

\section{REFERENCES}

[1] Dönmez S, Kavlak O. Effects of prenatal perineal massage and Kegel exercises on the integrity of postnatal perine. Health. 2015;7(04):495.

[2] Martini DE. Efektifitas Latihan Kegel Terhadap Percepatan Penyembuhan Luka Perineum Pada Ibu Nifas Di Puskesmas Kalitengah Lamongan. SURYA; 2015

[3] Makzizatunnisa EK, Hidayah N. Efektifitas Senam Kegel dan Relaksasi Nafas Dalam terhadap Nyeri Perinium pada Ibu Post Partum di Bpm Prima Boyolali. 2013

[4] Kurniati CH, Wulan IS, Hikmawati I. Analisis Pengetahuan Dan Tindakan Senam Kegel Terhadap Penyembuhan Luka Perineum Pada Ibu Nifas Di Wilayah Kerja Puskesmas Purwokerto Selatan. Pharmacy: Jurnal Farmasi Indonesia. 2014;11(01).

[5] Antini A, Trisnawati I, Darwanty J. Efektivitas Senam Kegel Terhadap Waktu Penyembuhan Luka Perineum Pada Ibu Post Partum Normal. Jurnal Penelitian Kesehatan" Suara forikes"(Journal of Health Research" Forikes Voice"). 2016;7(4):212-6

[6] Bobak IM, Lowdermilk D, Jensen M. Buku ajar keperawatan maternitas. Jakarta: EGC. 2005.

[7] Herlina H, Virgia V, Wardani RA. Hubungan teknik vulva hygiene dengan penyembuhan luka perinium pada ibu post partum. Jurnal Kebidanan Malahayati. 2018;4(1)

[8] Varney H, Kriebs JM, Gegor CL. Buku ajar asuhan kebidanan. Jakarta: EGC. 2007. 